\title{
REPORTING DISCLOSURE LEVELS AND COMPLIANCE WITH BB, AAOIFI, B/IFRS AND SEC OF ISLAMIC FINANCIAL INSTITUTIONS IN BANGLADESH
}

\author{
1Md. Robiul Islam, 2Mohammad Shamsus Sadekin \\ ${ }_{1} \mathrm{PhD}$ Fellow, Institute of Islamic Banking and Finance(IIBF), International Islamic University, Malaysia \\ 2Associate Professor (Accounting), Department of Humanities, Chittagong University of Engineering \& \\ Technology (CUET), Chittagong, Bangladesh. \\ E-mail:sadekinmba@yahoo.com,rrobiulbiu@gmail.com
}

\begin{abstract}
:
Compliance with financial reporting guidelines/standards promulgated by Regulatory Bodies has become a crucial issue of the day after a series of corporate debacles over a few years. Regulators, professional bodies and researchers throughout the world have expressed their concern about the need for improved accounting pronouncements and compliance for providing better information than previously required for the preparation and presentation of corporate financial reporting. The present study primarily focuses on the reporting disclosure levels and compliance with Bangladesh Bank (BB) Guidelines, Accounting and Auditing Organization for Islamic Financial Institutions (AAOIFI) Accounting Standard, Bangladesh/International Financial Reporting Standard (B/IFRS) and Securities and Exchange Commission (SEC) Rules of Islamic Financial Institutions in Bangladesh. Annual reports of (08) eight Islamic banks in Bangladesh have been examined for the year ending 2015. The results showed that the Islamic banks significantly followed the selected accounting guidelines/standards under review and did bring remarkable changes in the financial reporting practices made by the Islamic banks in Bangladesh. The study attempted to examine empirically the levels of disclosure in corporate annual reports of Islamic banks in Bangladesh. The study recommended increasing the level of compliance to make their financial reports more informative. The study also tries to ascertain the regulatory necessary requirements in preparing the financial statements of banks under Islamic shariah and tries to display the compliance status of these banks with legislations. The average compliance rate is 93.28\% for BB guidelines, $46.54 \%$ for AAOIFI Accounting Standard, $48.50 \%$ for B/IFRS and $51.99 \%$ for SEC rules considering all required aspects of financial reports. Compiling all of the requirements regarding financial reports of regulatory bodies will be helpful for banks to make financial reports convenient.
\end{abstract}

Keywords: Accounting Standards, Compliance, International Financial Reporting Standards, Corporate Attributes, International Accounting Standards Board, Corporate Governance, Transparency, Bangladesh

\section{Introduction}

The stated objectives of establishing the regulatory bodies was to pronounce a set of accounting standards for the banking industries with a view to facilitating relevant, reliable, adequate and uniform disclosure of accounting information in the financial statements. As the regulatory bodies made the transition to adulthood, its focus has become harmonization of financial reporting irrespective of international boundaries. This change in focus is due to banking companies, has increased the volume of economic exchanges across nations. The most recent spate of corporate collapses has thus place an increased mantle of responsibility on the shoulders of the regulatory bodies. The Bangladesh Bank, through a circular dated November 09, 2009, has introduced 'Guidelines for Islamic Banking', as a supplementary to the existing banking laws. The guidelines are to be followed by the Islamic banks and conventional commercial banks having Islamic branches, with a view to bringing greater transparency and accountability in Islamic 
banking. Accounting and Auditing Organization for Islamic Financial Institutions (AAOIFI) was established in 1990 and registered on March 27, 1991 in Bahrain. AAOIFI is an International Islamic autonomous nonprofit organization which sets accounting, auditing and governance standards for Islamic financial institutions. International Accounting Standards (IASs) are commonly known now as International Financial Reporting Standards (IFRSs), in Bangladesh it was adopted by ICAB known as BFRS. After the independence of Bangladesh in 1971, this ordinance and accounting rules were accepted as existing laws in Bangladesh and after that the Securities and Exchange Authority (SEC) was established. In 1987, the Government of Bangladesh took some important steps to enforce the aforesaid ordinance and rules. As a result, the Investment Wing of the Finance Division of the Ministry of Finance passed and enforced the Securities and Exchange Rules (SER), 1987.

If the enterprises within IASB member countries do not comply with the promulgated accounting or financial reporting standards, global harmonization will not be achieved. Professional accounting bodies of the member countries have joined with the IASB to achieve its objectives by calling for voluntary adoption or, where necessary, legal backing of international standards and practices. The Institute of Chartered Accountants of Bangladesh (ICAB) and The Institute of Cost and Management Accountants of Bangladesh (ICMAB) are members of IASB. But it is alleged that the role of these two bodies in the standard setting process and their implementation are not in equal in magnitudes. Owing to lack of legal backing, compliance with IASs remains at voluntary level until those become mandatory very recently by Securities and Exchange Commission (SEC) for the listed companies of Bangladesh. The present study opts for empirically examining the following aspects:

(a) The extent to which the Islamic banking companies in Bangladesh follow guidelines and standards; and

(b) The extent of disclosure for each of the items of information in its group as well as the overall grouping.

\section{Socio-Economic Settings and Development of Accounting Standards}

Compliance with guidelines/standards depends upon the politico-economic settings prevalent in a country. Most of the developing countries' industrialization, political institutions and culture are largely influenced by the socio-political tradition and philosophy of the colonial power by which they were ruled and therefore, the development of accounting standards in the developing countries is not an exception to this (Perera, 1989). Accounting development patterns of most developing countries are either imposed through colonial influence or by powerful investors or Multinational Companies (MNCs) (Chandler and Holzer, 1984; Beclkaoui, 1985 and Hove, 1986). Samuels and Oliga (1982) while evaluating accounting standards in developing countries argue that where economic, socio-political, cultural and contextual differences between countries, nations and societies exists, there is a problem of appropriate accounting standards. They argued that there are both conceptual and practical problems that expose the futility of harmonisation of accounting standards. Hove (1986) identified four vehicles (i.e., colonial rule, operations of transnational corporations, professional accounting institutions and the special conditions in foreign aid agreements) by which accounting technology was imposed by the developed countries on the developing countries. In many countries, of course, the British influence has had very long standing and this has impacted on the development of accounting standards. Bangladesh inherited its politics and large parts of law and administrative structure from the British. As a part of India, Bangladesh was ruled over by the British for about 200 years until 1947 and then 25 years by Pakistan until 1971. As a matter of fact, the country started with the lingua franca "bottomless basket" immediately after the liberation in 1971. Over the years the country has traversed through the vicious circle of poverty. Lack of governance and dependence on development aids are claimed to have had a far reaching impact on the socio-economic development of the country. Rahman and Jannah (2003) in a joint initiative taken by the World Bank and IMF drawing on "Reports on the Observance of Standards and Codes (ROSC) took a snap-shot of the real socio-economic characteristics of Bangladesh: 
"Despite sustained domestic and international efforts to improve economic and demographic prospects, Bangladesh remains poor. The country has a population of about 160 million within a geographic boundary of 143,998 square kilometres (56,160 square miles). Although more than half of the gross domestic product (GDP) is generated through the service sector, nearly two-thirds of the population are employed in agriculture. Major impediments to growth include frequent natural disasters, inefficient state-owned enterprises, inadequate infrastructure, weak private and foreign investments, and slow implementation of economic reforms. Weak national financial architecture, inadequate transparency and accountability, and a dearth of appropriate policy interventions are among the impediments cited for the country's slow economic development." Despite enormous bottlenecks, Bangladesh has been striving to rise above the curses of poverty and exhibits similar characteristics to other developing countries. These characteristics can be seen in the setting of accounting standards and compliance. For Islamic banking industries no special accounting rules and regulations had been used up to November 09, 2009 that had been first introduced by the Bangladesh Bank for preparing financial reporting. Since the Islamic banks were established in 1983 moreover no initiative had been taken by any authority.

\section{Objectives}

The reporting disclosure levels by the Islamic banks in the financial reports improve comparability for users and better facilitate of financial position, performance and Shariah compliance of Islamic banking activities. In the context of Bangladeshi Islami banking companies schedule banks operated under Islamic Shariah are to comply with the requirements of different regulators and legislations for constructing its financial reports. They are to comply with all of the regulations applicable for conventional banking and other specific regulations for Islamic banks.

The objective of the study was to determine the financial reporting standards that Islamic Financial Institutions (IFIs) are legally required and to examine the legislations that influence the Islamic banks in preparing their financial reports. The specific objectives of this study are:

(i) to find out the necessary requirements for preparing financial reports of Islamic Shariah Based Banks, and

(ii) to inspect the financial reports of Islamic shariah based banks for showing the status of compliance under Bangladesh Banks' guide lines, AAOIFI Accounting Standards, B/IFRS and SEC guidelines.

\section{Research Methods}

There are 56 scheduled banks in Bangladesh who operate under full control and supervision of Bangladesh Bank, which is empowered to do so through Bangladesh Bank Order, 1972 and Bank Company Act, 1991. The banking sector of Bangladesh comprises of four categories of scheduled banks. Scheduled Banks are classified into following types: state owned commercial banks (SOCBs) (6); specialized banks development finance institutions (SBDFIs) (2); private commercial banks (PCBs) (39); foreign commercial banks (FCBs) (9); (see Table 1). 


\section{Scheduled Banks in Bangladesh}

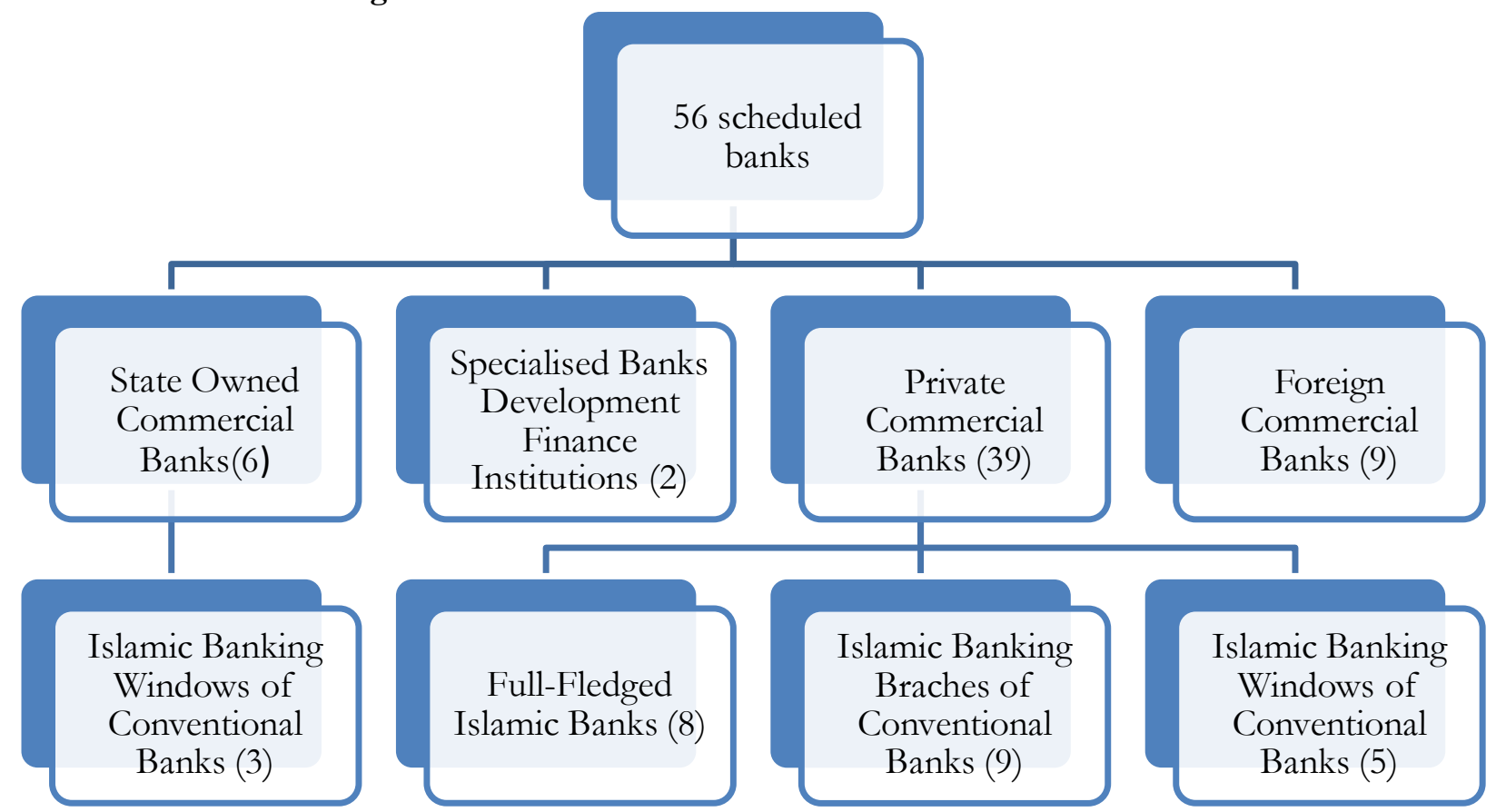

Source: Bangladesh Bank Annual Report 2014-2015, Page-29

\section{Selection of Accounting Guidelines/Standards}

There have been continuous changes in the B/IFRS and AAOIFI accounting standards in recent years. For the sake of our study, we considered four regulatory bodies' guidelines/standards that require maximum disclosure of information. The guidelines/standards that were chosen are:

i. Bangladesh Bank Guidelines for Islamic Banking

ii. Accounting and Auditing Organization for Islamic Financial Institutions (AAOIFI) Accounting Standard

iii. Bangladesh/International Financial Reporting Standard (B/IFRS); and

iv. Securities and Exchange Commission (SEC) Rules

As a source of data the study considered the annual reports of the year 2015 of selected banks. Data has been summarized by Microsoft Excel 2007 program.

\section{Sample Companies}

A survey of annual reports published by 08 (eight) Islamic Banking industries listed on Dhaka Stock Exchange (DSE) was carried out by the present researchers to examine the reporting disclosure level to which those Islamic banks have complied with the mandatory accounting guidelines/standards. The sample represents absolutely $100 \%$ of the population of the Islamic financial companies listed on the DSE.

\section{Literature Review}

There is a plethora of studies of financial reporting. This section reviews research on compliance with accounting standards. One of the main objectives of preparing financial statements is to provide more comparable data about the organization. At least the following four ways accounting standards assist the preparation of financial statement and comparability of organization's data: (i) mandating a specific presentation format (ii) compelling an explicit measurement technique (iii) ensuring an increasing level of disclosure and (iv) requiring the disclosure of additional information (Cairns 1995). Christopher and Islam (1999) have pointed out that developing countries increasingly need sophisticated accounting standards as 
their economies grow and become more complex.

Parry and Khan (1984) carried out a study of published annual reports of 74 entities in Bangladesh. Their major findings were that reports were generally informative and complied with legal requirements, but no attempt was taken to comply with regulatory bodies.

Alam (1989) found serious drawbacks in the provisions of the Companies Act, 1913 (currently the Companies Act 1994) relating to financial statements. He commented that in Bangladesh, the statutory requirements for the disclosure of accounting information are inadequate. As a result, development of accounting standards by considering the local national needs or compliance with the International Accounting Standards may be given utmost consideration.

Azizuddin (1991) while reviewing the accounting and auditing standards of the South Asian Federation of Accountants (SAFA) opined that the countries should urge upon the national government the need for the creation of machinery (a separate standard-setting agency) that will be authorised to develop and promulgate accounting standards.

Hauworth (1986) stated the problems in the development of worldwide accounting standards. There are the diversity of views regarding the purpose of financial statements, differences in the extent of development accounting professions, impact of tax laws on financial reporting, varies nature of the requirements of companies laws, difference in basic economic facts of the countries, lack of professional announcements and efforts for world-wide accounting standards (Hauworth, 1986). He suggested that world-wide accounting standards can be developed only when there is agreement on the objectives of financial statements and there is knowledge of the basic economic facts of the countries.

Rahim (1993) mentioned that a nation's financial reporting practices will be shaped by its socioeconomic structure. The cultural importation explanation states that the desire for international legitimacy creates incentives for developing nation to adopt western financial reporting practices. The author tried to determine the factors that have designed the corporate financial reporting practices in Bahrain. The author didn't agree with the previous researchers who offered two explanations, environmental factors and cultural importation, for the emergence of financial reporting practices in developing countries. The researcher observed that in Bahrain there has an excellent environment to examine the two explanations since its public and closed corporations have similar economic characteristics. Only public corporations are legally required to publish financial reports.

There are a few studies that examined the association between firm characteristics and the level of compliance with IFRSs and some studies observed that firm characteristics were positively associated with compliance, whereas others showed inconclusive results, demanding more research (Ali, 2005). Leimoni (1996) has found that there is an absence of well-defined reporting practices and procedures whereby such requirements, whether statutory or legal are strictly followed and enforced. Leimoni (1996) has argued that an attempt at improving the quality of accounting in Tonga, as a source of information function, would require a research study to accurately determine the country's needs, and the role of accounting in the country's economic development process.

Chavent et al (2006) opined that prior accounting research have examined the extent of disclosure and its determinants. Chavent et al (2006) argued that these studies have one major methodological drawback: the disclosure analysis is often restricted to determination of the disclosure index, that is, the sum of disclosed items, weighted or unweighted. They commented that the disclosure profile (which reflects the structure of published information) is generally not part of the research design. Chavent et al (2006) have introduced a divisive (descendant) clustering method, which splits the sample into homogeneous sub-groups corresponding to disclosure patterns (or profiles), for clearer determination of the financial characteristics of each group.

\section{Regulatory Requirements of Financial Reports of Islamic Shariah Based Banks}

The listed Shariah based banking companies are to follow several laws and regulations for preparing their financial reports. The banks are primarily registered with Registrar of Joint Stock Companies and Firms 
(RJSC) under the Companies Act 1994 as a public limited company. The important provisions regarding financial reporting have been laid down under Sections 181 to 185 and 192 of the Companies Act 1994. Section 181 directs to keep proper books of accounts whereas Section 183 requires to present audited balance sheet and profit and loss account in the annual general meeting. Section 185 prescribes the form and contents of balance sheet and profit and loss account of a company. Moreover, Section 192 states that every company being a limited banking company or an insurance company has to prepare the statements in accordance with Schedule XII, or as near thereto.

The Accounting and Auditing Organization for Islamic Financial Institutions (AAOIFI) was established in Bahrain at 1990 and registered on March 27, 1991. It is a non-profit autonomous organization which sets different standards for Islamic financial institutions. By this time this organization has been developed 26 accounting standards, 05 auditing standards, 07 governance standards, 02 ethics standards and 54 Shariah standards (www.aaoifi.com).

Among others Accounting Standard No. 1 (General presentation and disclosure in the financial statements of Islamic Financial Institutions) is more important for preparation of financial reporting of banks under Islamic Shariah. IBBL is an associate member of AAOIFI. Another organization, Islamic Financial Services Board (IFSB), is an international standard-setting organization that promotes and enhances the soundness and stability of the Islamic financial services industry by issuing global prudential standards and guiding principles for banking, capital markets and insurance sectors (www.ifsb.org). Bangladesh Bank is a full member and IBBL an observer member of this organization. The IFSB has issued 18 guiding principles, 06 guidance notes and 01 technical note since its foundation.

On November 09, 2009 Bangladesh Bank has been issued guidelines for Shariah based Islamic Banking in the Section 45 of Banking Companies Act, 1991. It had become necessary to introduce separate guidelines because there are some basic differences between the activities of Shariah based Islamic banking and general banking. These guidelines should be treated as supplementary, not substitute, to the existing banking laws, rules and regulations (Bangladesh Bank 2009).

The main objective of the guidelines on the Specimen Reports and Financial Statements for Banks under Islamic Shariah is to enable the banks to prepare their financial statements as per provisions of Banking Companies Act 1991, International Financial Reporting Standards, the Companies Act 1994, Accounting and Auditing Organization for Islamic Financial Institutions (AAOIFI) and Islamic Shariah. The prescribed format is applicable to full- fledged Islamic banks and Islamic branches of traditional commercial banks. It provides the minimum disclosure requirements of the banks under Islamic Shariah. These banks are to comply with the disclosure requirements of the Securities and Exchange Rules 1987, Stock Exchanges ${ }^{\text {ee }}$ Listing Regulations, IFRS, all the aspect of Islamic Shariah and AAOIFI.

\section{Analysis and Findings}

In Bangladesh 56 scheduled banks are doing their activities under full control and supervision of Bangladesh bank. These banks are doing their activities through Bangladesh Bank Order, 1972 and Bank Company Act, 1991. These schedule banks are classified into 04 categories like i. State-Owned Commercial Banks 06 ii. Specialized Banks Development Finance institutions (SBDFIs) 02 iii. Private Commercial Banks (PCBs) 39 iv. Foreign Commercial Banks (FCBs) 09 (see Table 1)

Table 1: Banking Systems Structure (Tk. in billion)

\begin{tabular}{|c|c|c|c|c|c|c|}
\hline \multirow{2}{*}{ Bank types } & \multicolumn{9}{|c|}{2014} \\
\cline { 2 - 6 } & $\begin{array}{c}\text { Numbe } \\
\text { r of } \\
\text { banks }\end{array}$ & $\begin{array}{c}\text { Number } \\
\text { of } \\
\text { branche } \\
\text { s }\end{array}$ & $\begin{array}{c}\text { Total } \\
\text { assets }\end{array}$ & $\begin{array}{c}\text { Percent } \\
\text { of } \\
\text { industr } \\
\text { y assets }\end{array}$ & $\begin{array}{c}\text { Deposit } \\
\text { s }\end{array}$ & $\begin{array}{c}\text { Percent } \\
\text { of } \\
\text { Deposit } \\
\text { s }\end{array}$ \\
\hline
\end{tabular}




\begin{tabular}{|l|c|c|c|c|c|c|}
\hline $\begin{array}{l}\text { State-owned Commercial Banks } \\
\text { (SCBs) }\end{array}$ & 5 & 3553 & $\begin{array}{c}2517 . \\
1\end{array}$ & 27.5 & 1952.1 & 28 \\
\hline $\begin{array}{l}\text { State-owned Development Financial } \\
\text { Institutions (DFIs) }\end{array}$ & 3 & 1500 & 333.8 & 3.7 & 237.6 & 3.4 \\
\hline Private Commercial Banks (PCBs) & 39 & 3917 & $\begin{array}{c}5787 . \\
1\end{array}$ & 63.3 & 4449.4 & 63.9 \\
\hline Foreign Commercial Banks (FCBs) & 9 & 70 & 505 & 5.5 & 326 & 4.7 \\
\hline Total & $\mathbf{5 6}$ & $\mathbf{9 0 4 0}$ & $\mathbf{9 1 4 3}$ & $\mathbf{1 0 0}$ & $\mathbf{6 9 6 5 . 1}$ & $\mathbf{1 0 0}$ \\
\hline
\end{tabular}

Source: Bangladesh Bank Annual Report 2014-2015, Page-29

Regulatory Bodies Compliance Status of Banks under Islamic Shariah for Preparing their Financial Reporting

Figure 1: Showing the Compliance with the Regulatory Bodies

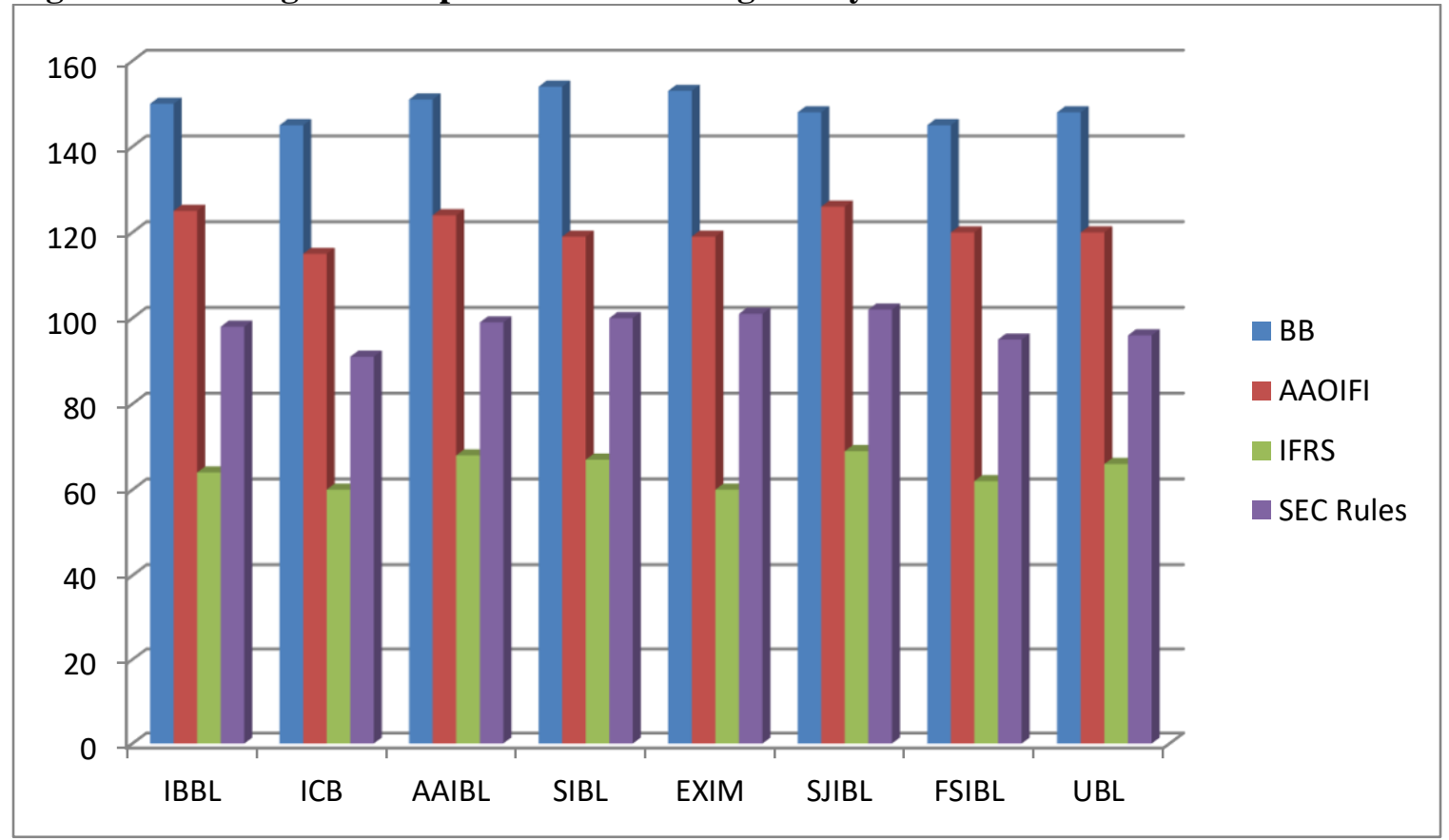

Sources: Annual Report 2015 of sample banks

Table 1: IBBL Compliance with the Regulatory Bodies

\begin{tabular}{|l|c|c|c|c|}
\hline \multirow{2}{*}{ Sl. } & $\begin{array}{c}\text { BB } \\
\text { Guidelines }\end{array}$ & $\begin{array}{c}\text { AAOIFI } \\
\text { Standards }\end{array}$ & $\begin{array}{c}\text { IAS/IFRS/BFRS } \\
\text { Standards }\end{array}$ & $\begin{array}{c}\text { Securities and } \\
\text { Exchange Rules }\end{array}$ \\
\cline { 2 - 5 } & $\mathbf{2 0 0 9}$ & $\mathbf{2 0 1 5}$ & $\mathbf{2 0 1 6}$ & $\mathbf{1 9 8 7}$ \\
\hline $\begin{array}{l}\text { Total } \\
\text { Disclosures }\end{array}$ & 160 & 260 & 133 & 188 \\
\hline $\begin{array}{l}\text { Compliance } \\
\text { Disclosures }\end{array}$ & 150 & 125 & 64 & 98 \\
\hline Compliance \% & $93.75 \%$ & $48.08 \%$ & $48.12 \%$ & $52.13 \%$ \\
\hline Mandatory \% & $140(87.50)$ & $75(28.85)$ & $33(24.81)$ & $77(40.96)$ \\
\hline Voluntary \% & $10(6.25)$ & $50(19.23)$ & $31(23.31)$ & $21(11.17)$ \\
\hline
\end{tabular}


Sources: IBBL Annual Report 2015

Table 2: ICB Compliance with the Regulatory Bodies

\begin{tabular}{|l|c|c|c|c|}
\hline \multirow{2}{*}{ Sl. } & $\begin{array}{c}\text { BB } \\
\text { Guidelines }\end{array}$ & $\begin{array}{c}\text { AAOIFI } \\
\text { Standards }\end{array}$ & $\begin{array}{c}\text { IAS/IFRS/BFRS } \\
\text { Standards }\end{array}$ & $\begin{array}{c}\text { Securities and } \\
\text { Exchange Rules }\end{array}$ \\
\cline { 2 - 5 } & $\mathbf{2 0 0 9}$ & $\mathbf{2 0 1 5}$ & $\mathbf{2 0 1 6}$ & $\mathbf{1 9 8 7}$ \\
\hline Total Disclosures & 160 & 260 & 133 & 188 \\
\hline $\begin{array}{l}\text { Compliance } \\
\text { Disclosures }\end{array}$ & 145 & 115 & 60 & 91 \\
\hline Compliance \% & $90.63 \%$ & $44.23 \%$ & $45.11 \%$ & $48.40 \%$ \\
\hline Mandatory \% & $135(84.38)$ & $68(26.15)$ & $25(18.80)$ & $75(39.89)$ \\
\hline Voluntary \% & $10(6.25)$ & $47(18.08)$ & $35(26.32)$ & $16(8.51)$ \\
\hline
\end{tabular}

Sources: ICB Annual Report 2015

Table 3: AAIBL Compliance with the Regulatory Bodies

\begin{tabular}{|l|c|c|c|c|}
\hline \multirow{2}{*}{ SI. } & BB Guidelines & $\begin{array}{c}\text { AAOIFI } \\
\text { Standards }\end{array}$ & $\begin{array}{c}\text { IAS/IFRS/BFRS } \\
\text { Standards }\end{array}$ & $\begin{array}{c}\text { Securities and } \\
\text { Exchange Rules }\end{array}$ \\
\cline { 2 - 5 } & $\mathbf{2 0 0 9}$ & $\mathbf{2 0 1 5}$ & $\mathbf{2 0 1 6}$ & $\mathbf{1 9 8 7}$ \\
\hline Total Disclosures & 160 & 260 & 133 & 188 \\
\hline $\begin{array}{l}\text { Compliance } \\
\text { Disclosures }\end{array}$ & 151 & 124 & 68 & 99 \\
\hline Compliance \% & $94.38 \%$ & $47.69 \%$ & $51.13 \%$ & $52.66 \%$ \\
\hline Mandatory\% & $140(87.50)$ & $70(26.92)$ & $40(30.08)$ & $80(42.55)$ \\
\hline Voluntary\% & $11(6.88)$ & $54(20.77)$ & $28(21.05)$ & $19(10.11)$ \\
\hline
\end{tabular}

Sources: AAIBL Annual Report 2015

Table 4: SIBL Compliance with the Regulatory Bodies

\begin{tabular}{|l|c|c|c|c|}
\hline \multirow{2}{*}{ Sl. } & BB Guidelines & $\begin{array}{c}\text { AAOIFI } \\
\text { Standards }\end{array}$ & $\begin{array}{c}\text { IAS/IFRS/BFRS } \\
\text { Standards }\end{array}$ & $\begin{array}{c}\text { Securities and } \\
\text { Exchange Rules }\end{array}$ \\
\cline { 2 - 5 } & $\mathbf{2 0 0 9}$ & $\mathbf{2 0 1 5}$ & $\mathbf{2 0 1 6}$ & $\mathbf{1 9 8 7}$ \\
\hline Total Disclosures & 160 & 260 & 133 & 188 \\
\hline $\begin{array}{l}\text { Compliance } \\
\text { Disclosures }\end{array}$ & 154 & 119 & 67 & 100 \\
\hline Compliance \% & $96.25 \%$ & $45.77 \%$ & $50.38 \%$ & $53.19 \%$ \\
\hline Mandatory \% & $142(88.75)$ & $77(29.62)$ & $36(27.07)$ & $79(42.02)$ \\
\hline Voluntary \% & $12(7.50)$ & $42(16.15)$ & $31(23.31)$ & $21(11.17)$ \\
\hline
\end{tabular}

Sources: SIBL Annual Report 2015

Table 5: EXIM Compliance with the Regulatory Bodies

\begin{tabular}{|l|c|c|c|c|}
\hline Sl. & BB & AAOIFI & IAS/IFRS/BFRS \\
Guidelines & Standards & Securities and Exchange \\
Rules
\end{tabular}




\begin{tabular}{|l|c|c|c|c|}
\hline & $\mathbf{2 0 0 9}$ & $\mathbf{2 0 1 5}$ & $\mathbf{2 0 1 6}$ & $\mathbf{1 9 8 7}$ \\
\hline Total Disclosures & 160 & 260 & 133 & 188 \\
\hline $\begin{array}{l}\text { Compliance } \\
\text { Disclosures }\end{array}$ & 153 & 119 & 60 & 101 \\
\hline Compliance \% & $95.63 \%$ & $45.77 \%$ & $45.11 \%$ & $53.72 \%$ \\
\hline Mandatory \% & $138(86.25)$ & $76(29.23)$ & $34(25.56)$ & $78(41.49)$ \\
\hline Voluntary \% & $15(9.38)$ & $43(16.54)$ & $26(19.55)$ & $23(12.23)$ \\
\hline
\end{tabular}

Sources: EXIM Annual Report 2015

Table 6: SJIBL Compliance with the Regulatory Bodies

\begin{tabular}{|l|c|c|c|c|}
\hline \multirow{2}{*}{ Sl. } & $\begin{array}{c}\text { BB } \\
\text { Guidelines }\end{array}$ & $\begin{array}{c}\text { AAOIFI } \\
\text { Standards }\end{array}$ & $\begin{array}{c}\text { IAS/IFRS/BFRS } \\
\text { Standards }\end{array}$ & $\begin{array}{c}\text { Securities and } \\
\text { Exchange Rules }\end{array}$ \\
\cline { 2 - 5 } & $\mathbf{2 0 0 9}$ & $\mathbf{2 0 1 5}$ & $\mathbf{2 0 1 6}$ & $\mathbf{1 9 8 7}$ \\
\hline Total Disclosures & 160 & 260 & 133 & 188 \\
\hline $\begin{array}{l}\text { Compliance } \\
\text { Disclosures }\end{array}$ & 148 & 126 & 69 & 102 \\
\hline Compliance \% & $92.50 \%$ & $48.46 \%$ & $51.88 \%$ & $54.26 \%$ \\
\hline Mandatory \% & $137(85.63)$ & $75(28.85)$ & $36(27.07)$ & $75(39.89)$ \\
\hline Voluntary \% & $11(6.88)$ & $51(19.62)$ & $33(24.81)$ & $27(14.36)$ \\
\hline
\end{tabular}

Sources: SJIBL Annual Report 2015

Table 7: FSIBL Compliance with the Regulatory Bodies

\begin{tabular}{|l|c|c|c|c|}
\hline \multirow{2}{*}{ Sl. } & $\begin{array}{c}\text { BB } \\
\text { Guidelines }\end{array}$ & $\begin{array}{c}\text { AAOIFI } \\
\text { Standards }\end{array}$ & $\begin{array}{c}\text { IAS/IFRS/BFRS } \\
\text { Standards }\end{array}$ & $\begin{array}{c}\text { Securities and } \\
\text { Exchange Rules }\end{array}$ \\
\cline { 2 - 5 } & $\mathbf{2 0 0 9}$ & $\mathbf{2 0 1 5}$ & $\mathbf{2 0 1 6}$ & $\mathbf{1 9 8 7}$ \\
\hline Total Disclosures & 160 & 260 & 133 & 188 \\
\hline $\begin{array}{l}\text { Compliance } \\
\text { Disclosures }\end{array}$ & 145 & 120 & 62 & 95 \\
\hline Compliance \% & $90.63 \%$ & $46.15 \%$ & $46.62 \%$ & $50.53 \%$ \\
\hline Mandatory \% & $132(82.50)$ & $72(27.69)$ & $40(30.08)$ & $81(43.09)$ \\
\hline Voluntary \% & $13(8.13)$ & $48(18.46)$ & $22(16.54)$ & $14(7.45)$ \\
\hline
\end{tabular}

Sources: FSIBL Annual Report 2015

Table 8: UBL Compliance with the Regulatory Bodies

\begin{tabular}{|l|c|c|c|c|}
\hline \multirow{2}{*}{ Sl. } & $\begin{array}{c}\text { BB } \\
\text { Guidelines }\end{array}$ & $\begin{array}{c}\text { AAOIFI } \\
\text { Standards }\end{array}$ & $\begin{array}{c}\text { IAS/IFRS/BFRS } \\
\text { Standards }\end{array}$ & $\begin{array}{c}\text { Securities and Exchange } \\
\text { Rules }\end{array}$ \\
\cline { 2 - 5 } & $\mathbf{2 0 0 9}$ & $\mathbf{2 0 1 5}$ & $\mathbf{2 0 1 6}$ & $\mathbf{1 9 8 7}$ \\
\hline Total Disclosures & 160 & 260 & 133 & 188 \\
\hline $\begin{array}{l}\text { Compliance } \\
\text { Disclosures }\end{array}$ & 148 & 120 & 66 & 96 \\
\hline \% Compliance & $92.50 \%$ & $46.15 \%$ & $49.62 \%$ & $51.06 \%$ \\
\hline
\end{tabular}

International Journal of Economics, Business and Accounting Research (IJEBAR) Page 118 


\begin{tabular}{|l|c|c|c|c|} 
Mandatory \% & $138(86.25)$ & $82(31.54)$ & $42(31.58)$ & $83(44.15)$ \\
\hline Voluntary \% & $10(6.25)$ & $38(14.62)$ & $24(18.05)$ & $13(6.91)$ \\
\hline
\end{tabular}

Sources: UBL Annual Report 2015

After considering the different standards, laws and regulations the following requirements have been classified into 04 categories, i.e., (i) refereeing the legislation as complied, (ii) disclosure in the face of financial statements, (iii) disclosure of information in the notes as a part of financial statements and (iv) other requirements.

Table 1 represents the summary of regulatory of the banks. The legislations which have been followed to prepare the financial statements, banks should disclose these rules. The average compliance rate is $93.28 \%$ for BB guidelines, $46.54 \%$ for AAOIFI Accounting Standard, $48.50 \%$ for B/IFRS and $51.99 \%$ for SEC rules considering all required aspects of financial reports.

In this study it has been focused on materiality. The researchers believe that the concept of materiality and the lack of its appropriate application is a key contributor to the excessive disclosures in financial reports. If the concept of materiality was applied successfully then immaterial information that clouds more relevant information would be removed. This means that the performance and the position of the entity would be more visible. The concept of materiality needs to be clearly understood so that it can be applied appropriately. Effective application of the concept of materiality requires professional judgement. It suggests that auditing seems to have become more focused on compliance. Investors pay auditors for their

Table 9: Overall Compliance Ratio among the Sample Banks on different Regulatory Bodies

\begin{tabular}{|l|l|c|c|c|c|}
\hline \multirow{2}{*}{ S1. } & \multirow{2}{*}{ Name of Banks } & $\begin{array}{c}\text { BB } \\
\text { Guidelines }\end{array}$ & $\begin{array}{c}\text { AAOIFI } \\
\text { Standards }\end{array}$ & $\begin{array}{c}\text { IAS/IFRS/BF } \\
\text { RS Standards }\end{array}$ & $\begin{array}{c}\text { Securities and } \\
\text { Exchange } \\
\text { Rules }\end{array}$ \\
\cline { 3 - 5 } & & 2009 & 2015 & 2016 & 1987 \\
\hline 1 & IBBL Total Compliance \% & $93.75 \%$ & $48.08 \%$ & $48.12 \%$ & $52.13 \%$ \\
\hline 2 & ICB Total Compliance \% & $90.63 \%$ & $44.23 \%$ & $45.11 \%$ & $48.40 \%$ \\
\hline 3 & AAIBL Total Compliance \% & $94.38 \%$ & $47.69 \%$ & $51.13 \%$ & $52.66 \%$ \\
\hline 4 & SIBL Total Compliance \% & $96.25 \%$ & $45.77 \%$ & $50.38 \%$ & $53.19 \%$ \\
\hline 5 & EXIM Total Compliance \% & $95.63 \%$ & $45.77 \%$ & $45.11 \%$ & $53.72 \%$ \\
\hline 6 & SJIBL Total Compliance \% & $92.50 \%$ & $48.46 \%$ & $51.88 \%$ & $54.26 \%$ \\
\hline 7 & FSIBL Total Compliance \% & $90.63 \%$ & $46.15 \%$ & $46.62 \%$ & $50.53 \%$ \\
\hline 8 & UBL Total Compliance \% & $92.50 \%$ & $46.15 \%$ & $49.62 \%$ & $51.06 \%$ \\
\hline \multicolumn{2}{|l|}{ Total } & $746.27 \%$ & $372.30 \%$ & $387.97 \%$ & $415.95 \%$ \\
\hline \multicolumn{2}{|l|}{ Average } & $93.28 \%$ & $46.54 \%$ & $48.50 \%$ & $51.99 \%$ \\
\hline
\end{tabular}

According to the Table 2 we have found that among the sample banks SIBL shows the highest total compliance of $96.25 \%$ and FSIBL shows the lowest total compliance $90.63 \%$ for BB guidelines. SJIBL shows the highest total compliance of $48.46 \%$ and ICB shows the lowest total compliance $44.23 \%$ for AAOIFI accounting standards. Accordingly, SJIBL shows the highest total compliance of $51.88 \%$ and ICB \& EXIM banks shows the lowest total compliance of $45.11 \%$ for B/IFRS. Finally, SJIBL shows the highest total compliance of $54.26 \%$ and ICB shows the lowest total compliance of $48.40 \%$ for ICB total compliance.

Some banks did not refer the Company Act 1994, the Listing Regulations of Dhaka Stock Exchange/Chittagong Stock Exchange and/or Accounting and Auditing Organization for Islamic Financial Institutions /Bangladesh Bank/ International Financial Reporting Standards. But those legislations have to comply by them with the necessary requirements. Out of 08 Islamic banks, no banks have been prepared 
their financial statements by complying regulatory requirements fully whereas minimum compliance rate is $46.54 \%$ for AAOIFI accounting standard.

Figure 2: IBBL Compliance with 2013, 2014 and 2015

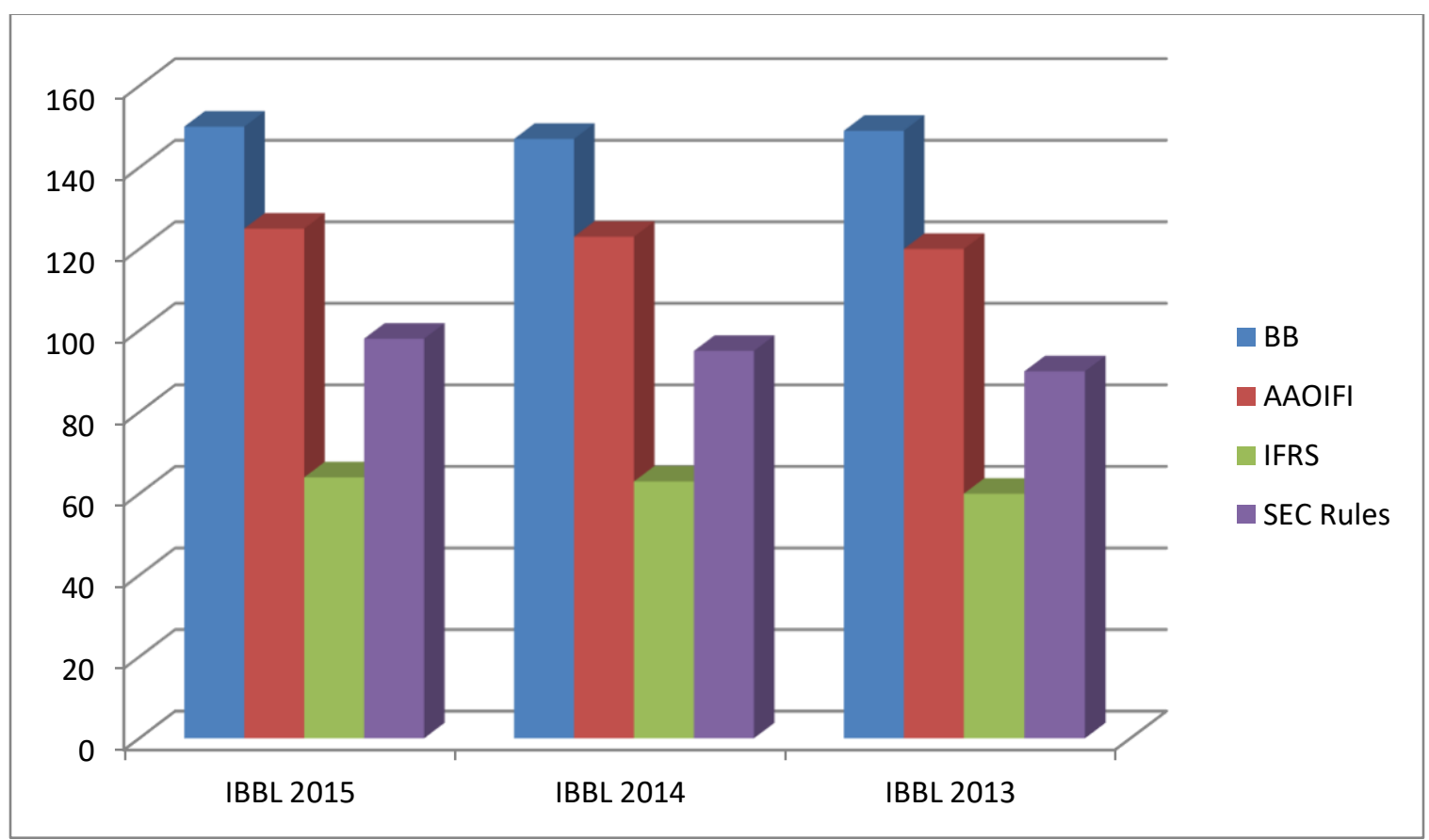

Table 10: IBBL Compliance with the Regulatory Bodies

\begin{tabular}{|c|c|c|c|c|}
\hline \multirow[t]{2}{*}{ SI } & $\begin{array}{c}\text { BB } \\
\text { Guidelines } \\
\end{array}$ & $\begin{array}{c}\text { AAOIFI } \\
\text { Standards }\end{array}$ & $\begin{array}{c}\text { IAS/IFRS/BFRS } \\
\text { Standards } \\
\end{array}$ & $\begin{array}{c}\text { Securities and } \\
\text { Exchange Rules }\end{array}$ \\
\hline & 2009 & 2015 & 2016 & 1987 \\
\hline \multicolumn{5}{|c|}{ Compliance with 2013} \\
\hline Total Disclosures & 160 & 260 & 133 & 188 \\
\hline $\begin{array}{l}\text { Compliance } \\
\text { Disclosures }\end{array}$ & 149 & 120 & 60 & 90 \\
\hline$\%$ Compliance & $93.13 \%$ & $46.15 \%$ & $45.11 \%$ & $47.87 \%$ \\
\hline \multicolumn{5}{|c|}{ Compliance with 2014} \\
\hline Total Disclosures & 160 & 260 & 133 & 188 \\
\hline $\begin{array}{l}\text { Compliance } \\
\text { Disclosures } \\
\end{array}$ & 147 & 123 & 63 & 95 \\
\hline$\%$ Compliance & $91.88 \%$ & $47.31 \%$ & $47.37 \%$ & $50.53 \%$ \\
\hline \multicolumn{5}{|c|}{ Compliance with 2015} \\
\hline Total Disclosures & 160 & 260 & 133 & 188 \\
\hline $\begin{array}{l}\text { Compliance } \\
\text { Disclosures: } 2015\end{array}$ & 150 & 125 & 64 & 98 \\
\hline$\%$ Compliance & $93.75 \%$ & $48.08 \%$ & $48.12 \%$ & $52.13 \%$ \\
\hline
\end{tabular}


Sources: IBBL Annual Report 2013, 2014, and 2015

\section{Conclusion}

The differences in financial reporting appear to stem from directives issued by regulators and central banks. For example, a national standard-setter may require IFRS compliance, but a regulator or central bank issues an overriding directive that result in departure from an IFRS requirement. Hence, any effort to improve the comparability of the general purpose financial statements of Islamic financial institutions must involve preparers, standard-setters, regulators and central banks. Different regulatory authorities impose different regulations to bring greater transparency and accountability and to ensure good governance in the banking industry. For these purpose all the requirements should comply by the banks. Banks are doing business with public money. It is highly a leveraged industry. Customers trust and confidence is the heart of banking business. So, customer loyalty should be the prime concern of banks. Besides, most of the customers of Islamic banks are religious by nature and want to comply with Shariah. For this reason, it is important for Shariah based banks to obey all of the laws, regulations and guidelines. It is also important to ensure the transparency by making proper disclosures. The average compliance rate is $93.28 \%$ for BB guidelines, 46.54\% for AAOIFI Accounting Standard, $48.50 \%$ for B/IFRS and 51.99\% for SEC rules considering all required aspects of financial reports. Bank should induce all the requirements of regulatory bodies to prepare financial report conveniently. But it will be appreciable if the stakeholders see the full compliance with disclosure requirements. In Bangladesh, $\mathrm{AB}$ Banks Limited are complying with all disclosure requirements as set by Bangladesh Banks (Hossain, 2012). It would be very easy for banks to comply with these requirements if the Bank Companies Act, 1991 makes it mandatory to compile all of the disclosure requirements (Hossain, 2011). As per the guidelines of IFSB 4, Bangladesh Bank should come forward to find ways of harmonizing the differences among different legislations. Compiling all of the requirements regarding financial statements of banks under Islamic Shariah Bangladesh Bank may modify BRPD Circular No. 15/2009. Though the current study does not give model, the concerned banks and regulators may consider the findings of this study for their future course of actions. Regulators and standard-setters should set standards that do not read as rules or checklists. Instead they should provide principle-based guidance that helps people to do their job better rather than forcing them into a certain pattern of disclosure. Addressing performance reporting is an important aspect of this goal. It is noted that this was a strong message in the feedback received on the IASB's Agenda Consultation 2011. It can be concluded by observing that using professional judgment will mean that sometimes things can go wrong-sometimes, the right things may not be disclosed; however this would be better than what we have now, where disclosures are wrong all the time. Compiling all of the requirements regarding financial reports Bangladesh Bank may modify BRPD Circular No. 15/2009 that will be helpful for banks to prepare financial reports conveniently. 


\section{References}

AAOIFI (2003) "Concepts of Financial Accounting for Islamic Banks and Financial Institutions." Accounting, Auditing and Governance Standards for Islamic Financial Institutions, paragraph 51, page 36.

AAOIFI (2010) "Conceptual Framework for Financial Reporting by Islamic Financial Institutions." Accounting, Auditing and Governance Standards for Islamic Financial Institutions, paragraph 6.3, page 16.

Alam S A K M (1989) "Corporate Financial Reporting in SAFA Countries- Bangladesh Context." The Accountant, the Institute of Chartered Accountants of Bangladesh, Vol.XII, No. 2, April-June, pp. 14-22.

Azizuddin A B M (1991) "Status of Accounting and Audit Standards in SAFA Countries." The proceedings of The Sixth SAFA Conference, the Institute of Chartered Accountants of Bangladesh (ICAB) and the Institute of Cost and Management Accountants of Bangladesh (ICMAB), Dhaka, Bangladesh.

Chandler J S and Holzer H P (1984) "Accounting in Third World", in P.F. Holzer et al (eds.) International Accounting (Harper and Row: New York).

Chavent M et.al. (2006) "Disclosure and Determinants Studies: An Extension Using the Divisive Clustering Method (DIV)." European Accounting Review, Vol. 15, Issue 2, pp. 181-218.

Christopher T and Islam A (1999) "Adoption of IAS in the Third World Counties: An Explanatory Model." Conference Proceedings, Third International Conference on International Accounting and Management Issues, Bangalore, India, pp.19-37.

Hauworth W O (1993) "Problems in Development of Worldwide Accounting Standards", International Journal of Accounting, pp.23-34.

Hove M R (1986) “Accounting Practices in Developing Countries: Colonialism's Legacy of Inappropriate Technologies" The International Journal of Accounting, Fall, 22(1), pp. 81-100.

10] Parry M J and Khan F A (1984) A Survey of Published Accounts in Bangladesh, (ICAB and UN Department of Technical Cooperation for Development, Dhaka, June).

Perera M.H.B (1989) Accounting in Developing Countries: A Case for Localised Uniformity, The British Accounting Review, June 21.

Rahim H M A (1993) "An Analysis of Corporate Accounting and Reporting Practices in Bahrain" PHD Thesis, Denton, Texas

Rahman M Z and Zannah S (2003), Reports on the Observance of Standards and Codes (ROSC) Bangladesh, Accounting and Auditing (World Bank and IMF, May 16).

Samuels J M. and Oliga J C (1982) "Accounting Standards in Developing Countries", The International Journal of Accounting Education and Research, Fall, (1), pp. 69-88. 